\title{
Proton Secretion by the Sodium/Hydrogen Ion Antiporter in the Human Neutrophil
}

\author{
Jonathan Wright, John H. Schwartz, Richard Olson, Joshua M. Kosowsky, and Alfred I. Tauber \\ William B. Castle Hematology Research Laboratory, Boston City Hospital, and the Departments of Medicine and Biochemistry, \\ Boston University School of Medicine, Boston, Massachusetts 02118
}

\begin{abstract}
The reducing equivalents used by the human neutrophil respiratory burst oxidase are derived from NADPH generated by the hexose monophosphate shunt. The $\mathrm{CO}_{2}$ generated by the HMP shunt is spontaneously hydrated and the protons $\left(\mathrm{H}^{+}\right)$are secreted upon the dissociation of carbonic acid. The mechanism and significance of $\mathrm{H}^{+}$secretion by the resting and stimulated neutrophil was investigated. A basal rate of $\mathrm{H}^{+}$secretion by resting neutrophils observed in a choline buffer was augmented with the addition of sodium $\left(\mathrm{Na}^{+}\right)\left(\mathrm{K}_{\mathrm{m}}\right.$ for $\mathrm{Na}^{+}$was $3.22 \pm 0.32$ mM). Amiloride, a $\mathrm{Na}^{+} / \mathrm{H}^{+}$antiporter inhibitor, reduced $\mathrm{H}^{+}$ secretion in $\mathrm{Na}^{+}$-containing buffers with a $K_{\mathrm{i}}=1.02 \mu \mathrm{M}$. This $\mathrm{Na}^{+} / \mathrm{H}^{+}$exchange mechanism was also operative in cells stimulated with a variety of agonists, and an increased $\mathrm{H}^{+}$flux, relative to resting cells, was observed at higher $\mathrm{Na}^{+}$concentrations.

Cytoplasts incorporating acridine orange were also used to assess $\mathrm{Na}^{+}-\mathrm{H}^{+}$flux. Cytoplasts were used to avoid alteration of the fluorescent $\mathrm{pH}$ probe by $\mathrm{HOCl}$ formed in intact neutrophils. Alkalinization of the cytoplasm was dependent on extracellular $\mathrm{Na}^{+}$in concentrations similar to that found to augment $\mathrm{H}^{+}$secretion in intact cells. Also, amiloride competitively inhibited $\mathrm{H}^{+}$secretion by the cytoplasts.

Both superoxide $\left(\mathrm{O}_{2}^{-}\right)$production and lysozyme release in cells stimulated with opsonized zymosan or concanavalin A was significantly inhibited in the absence of $\mathrm{Na}^{+}$, restored to normal with the addition of $\mathrm{Na}^{+}$in low concentrations, and inhibited again in the presence of amiloride. $\mathrm{A} \mathrm{Na} / \mathrm{H}^{+}$antiporter similar to that found in other cell types is present in the human neutrophil and appears linked to activation of the respiratory burst and degranulation.
\end{abstract}

\section{Introduction}

The human neutrophil, when stimulated by various agonists, reduces molecular oxygen in a cyanide-insensitive respiratory burst to form reactive oxygen species (1). The respiratory burst oxidase has been characterized as a membrane-bound NADPHoxidase, which generates the one electron reduction product, superoxide $\left(\mathrm{O}_{2}^{-}\right)(2)$. The reducing equivalents are derived from the reduced pyridine nucleotide, NADPH, which is generated in the concomitant activation of the hexose monophosphate

Address correspondence to Dr. Wright, Boston City Hospital.

Received for publication 16 January 1985 and in revised form 2 October 1985.

J. Clin. Invest.

(C) The American Society for Clinical Investigation, Inc.

0021-9738/86/03/0782/07 \$1.00

Volume 77, March 1986, 782-788
(HMP) ${ }^{1}$ shunt (2). Previous studies from this laboratory have demonstrated that the activity of the HMP shunt may be ascertained by the quantitation of $\mathrm{CO}_{2}$ production, and that the ratio of $\mathrm{CO}_{2}$ formed to oxygen consumed is near unity (3). The $\mathrm{CO}_{2}$ is spontaneously hydrated and the protons $\left(\mathrm{H}^{+}\right)$are secreted upon the dissociation of carbonic acid. While resting cells secrete protons at a lower rate, the source in this instance is lactate and not the HMP shunt $(3,4)$.

In this study, the mechanism of $\mathrm{H}^{+}$secretion in the human neutrophil was examined. The importance of cation exchange was suggested by the previous findings that substitution of isotonic glucose for sodium $\left(\mathrm{Na}^{+}\right)$markedly depressed $\mathrm{O}_{2}^{-}$production in neutrophils stimulated with formyl-methionyl-leucylphenylalanine (FMLP) (5). Further, replacement of $\mathrm{Na}^{+}$with $\mathrm{K}^{+}$or choline depressed $\mathrm{O}_{2}^{-}$production, lysosomal enzyme release, and the hyperpolarization response in concanavalin $\mathrm{A}$ (Con A) or immune complex-stimulated neutrophils (6). A recent report has demonstrated that extracellular $\mathrm{Na}^{+}$regulates the respiratory and secretory threshold response to FMLP (7), which is likely due to modulation of receptor sensitivity (8). A ouabainsensitive $\mathrm{Na}^{+}$electrogenic pump has been reported in the neutrophil, which correlates with neutrophil membrane hyperpolarization and computed membrane conductance, but the role of this pump in neutrophil stimulus-coupled activation pathways is undefined (9). A Na ${ }^{+}$-coupled mechanism for active $\mathrm{H}^{+}$secretion has been suggested in studies with rabbit neutrophils, but the mechanism has not been further elucidated (10). Amiloride-sensitive $\mathrm{Na}^{+} / \mathrm{H}^{+}$exchange has been reported in $\mathrm{HL}-60$ cells and has been implicated as important for cellular differentiation (11). $\mathrm{Na}^{+} / \mathrm{H}^{+}$exchange has also been reported as important in neutrophils for the normalization of intracellular $\mathrm{pH}$ in acid-loaded cells (12); however, the mechanism of exchange has not been characterized, nor has its role in the respiratory burst activation been investigated.

In our study of augmented $\mathrm{H}^{+}$secretion of stimulated neutrophils, we have endeavored to determine the transport mechanism, and here propose that it involves the same $\mathrm{Na}^{+} / \mathrm{H}^{+}$antiporter characterized in the renal microvillus membrane (13). In the microvillus preparation the antiporter is electroneutral, with a $\mathrm{Na}^{+} / \mathrm{H}^{+}$coupling ratio of 1.0 , and mediates no net fluxes of $\mathrm{Na}^{+}$and $\mathrm{H}^{+}$whenever the respective transmembrane gradients are balanced. The $K_{\mathrm{m}}$ for $\mathrm{Na}^{+}$in this preparation is $6-13 \mathrm{mM}$, and the exchange is specifically inhibited by amiloride at low concentration. The secretion of $\mathrm{H}^{+}$associated with the respiratory burst of the human neutrophil is here examined to de-

1. Abbreviations used in this paper: Con A, concanavalin A; Con A FITC, Con A fluorescein isothiocyanate; FMLP, formyl-methionyl-leucylphenylalanine; HMP, hexose monophosphate; OZ, opsonized zymosan; SITS, 4-acetamido-4'-isothiocyano-2,2'-disulfonic acid stilbene; SOD, superoxide dismutase. 
termine whether electroneutral exchange with $\mathrm{Na}^{+}$is a significant mechanism of $\mathrm{H}^{+}$flux in the activated cell. Further, we have examined the importance of this exchange in the function of the stimulated neutrophil.

\section{Methods}

Ouabain, choline chloride, $\alpha$-methylmannoside, phorbol myristate acetate, trypan blue, superoxide dismutase (SOD), Con A, Con A fluorescein isothiocyanate (Con A FITC), cytochalasin B, acridine orange, zymosan and monensin were purchased from Sigma Chemical Co. (St. Louis, MO), and the other reagents, 5,6-carboxyfluorescein (Molecular Probes, Junction City, OR), 4-acetamido-4'-isothiocyano-2,2'-disulfonic acid stilbene (SITS), and valinomycin (Calbiochem-Behring Corp., La Jolla, $\mathrm{CA}$ ), were obtained as listed. Amiloride $\mathrm{HCl}$ and dimethylamiloride were kindly provided by Merck Sharp \& Dohme Div., Merck \& Co., Inc., West Point, PA.

Neutrophils were isolated from healthy volunteers by red cell sedimentation in Dextran-citrate, followed by hypotonic lysis and FicollHypaque density centrifugation as previously described (3). For studies in $\mathrm{Na}^{+}$-free buffers, the neutrophils were suspended in $145 \mathrm{mM}$ choline chloride, $5 \mathrm{mM}$ glucose, $1 \mathrm{mM} \mathrm{K}_{2} \mathrm{HPO}_{4}, 0.8 \mathrm{mM} \mathrm{CaCl}_{2}$, and $0.8 \mathrm{mM}$ $\mathrm{MgSO}_{4}, \mathrm{pH}$ 7.42. Sodium chloride $(\mathrm{NaCl})$ was added as indicated. The physiological control buffer (phosphate-buffered saline [PBS]) consisted of $145 \mathrm{mM} \mathrm{NaCl}$ and like concentrations of phosphate, calcium, and magnesium as used above (2). The $\mathrm{Na}^{+}$-free buffers were checked for $\mathrm{Na}^{+}$content by flame photometry, and $\mathrm{Na}^{+}$was never detectable.

Proton secretion. Cells at a concentration of $5 \times 10^{6}$ cells $/ \mathrm{ml}$ were added to $8 \mathrm{ml}$ of indicated buffer and were incubated at $37^{\circ} \mathrm{C}$ with constant stirring in a YSI model 5301 bath stirrer assembly (Yellow Springs Instruments, Yellow Springs, CO) connected to a Haake Water circulator (Haake Instruments, Rochelle Park, NJ). A pH titration unit with a model PHM 62 pH-meter (Radiometer, Copenhagen, Denmark) maintained $\mathrm{pH}$ at 7.42 by automatic titration with $0.015 \mathrm{~N} \mathrm{NaOH}$ delivered from an autoburette unit. $\mathrm{H}^{+}$secretion was quantitated from the amount of $\mathrm{NaOH}$ titrated to maintain the $\mathrm{pH}$ at 7.42 as previously described (3). Proton secretion in stimulated cells was measured after 3 min of preincubation in designated buffers with opsonized zymosan $(\mathrm{OZ})$ $(1.5 \mathrm{mg} / \mathrm{ml})$, or Con $\mathrm{A}(100 \mu \mathrm{g} / \mathrm{ml})$. In cells stimulated with Con $\mathrm{A}$, the cells were preincubated with $5 \mu \mathrm{g} / \mathrm{ml}$ cytochalasin B.

Cytoplasts. Cytoplasts were made exactly as described by Roos et al. (14), which necessitated minimal modification of our usual procedure for isolation of neutrophils. Alkaline phosphatase and myeloperoxidase were assessed as previously described (15), with results similar to those reported (14). Cytoplasts from $2 \mathrm{U}$ of blood were incubated for $1 \mathrm{~h}$ at $4^{\circ} \mathrm{C}$ in PBS, pH 6.0, washed three times in a solution of $200 \mathrm{mM}$ sucrose, $10 \mathrm{mM}$ Hepes, and $10 \mathrm{mM}$ Tris base, $\mathrm{pH} \mathrm{6.0,} \mathrm{and} \mathrm{then} \mathrm{resuspended} \mathrm{in}$ the same buffer to a protein concentration of $25 \mathrm{mg} / \mathrm{ml}$. Acridine orange was added to a final concentration of $0.6 \mu \mathrm{M}$ in $2 \mathrm{ml}$ of the same sucrose buffer but adjusted to $\mathrm{pH} 7.5$. Fluorescence was measured at $37^{\circ} \mathrm{C}$ in a Perkin-Elmer fluorescence spectrophotometer (model 650-10S), using an excitation wavelength of $493 \mathrm{~nm}$ and an emission wavelength of 530 $\mathrm{nm}$ (16). After equilibration of the signal, $25 \mu \mathrm{l}$ of the cytoplast preparation were added under constant stirring and an immediate decline in the signal was observed. Again, after equilibration, various concentrations of $\mathrm{NaCl}$ were added and the initial slope of the subsequent increase in emission (signifying alkalinization) was recorded. The experiments were done with and without sodium azide at $10^{-4} \mathrm{M}$ to eliminate any possible change in the dye signal due to the effects of $\mathrm{HOCl}$ produced by the myeloperoxidase system (17). Experiments were also done with various $\mathrm{Na}^{+}$concentrations in samples preincubated with $50 \mu \mathrm{M}$ amiloride. To rule out the possible contribution of $\mathrm{Cl}^{-}$-dependent $\mathrm{H}^{+}$secretion, the change in fluorescence was noted after addition of $25 \mathrm{mM}$ sodium cyclamate to the same buffer, and compared with addition of the same concentration of $\mathrm{NaCl}$. To insure that the process observed was electroneutral, cytoplasts were suspended in a high $\mathrm{K}^{+}$buffer $(100 \mathrm{mM} \mathrm{KCl}$, $10 \mathrm{mM}$ Hepes, and $10 \mathrm{mM}$ Tris base, $\mathrm{pH} 7.5$ ) and alkalinization was observed with addition of $25 \mathrm{mM} \mathrm{NaCl}$ in the presence and absence of $5 \mu \mathrm{g} / \mathrm{ml}$ valinomycin.

Neutrophil functional assays. The generation of $\mathrm{O}_{2}^{-}$by the SODinhibitable reduction of cytochrome $c$ was measured by the continuous method previously described (2). Stimuli employed were $\mathrm{OZ}(1.5 \mathrm{mg} /$ $\mathrm{ml})$ and Con $\mathrm{A}(100 \mu \mathrm{g} / \mathrm{ml})$ under conditions identical to those employed for the proton secretion studies. The respiratory burst NADPH-oxidase was harvested from PMA-stimulated neutrophils and activity measured as detailed previously (2). Oxygen consumption studies were concomitantly performed to verify $\mathrm{O}_{2}^{-}$results, according to our described methods $(2,3)$.

For lysozyme release studies, $5 \times 10^{6}$ cells $/ \mathrm{ml}$ were preincubated at $37^{\circ} \mathrm{C}$ with $5 \mu \mathrm{g} / \mathrm{ml}$ cytochalasin B for $5 \mathrm{~min}$ and then stimulated with Con A $(100 \mu \mathrm{g} / \mathrm{ml})$. After $15 \mathrm{~min}$ at $37^{\circ} \mathrm{C}$, the cells were pelleted at 200 $g$ for 6 min and lysozyme content was assayed in the supernatant and pellet as previously described (18).

The effect of varying $\mathrm{Na}^{+}$concentrations on Con $\mathrm{A}$ binding was determined. Con A FITC was dialyzed exhaustively against a $\mathrm{Na}^{+}$-free choline buffer. Neutrophils $\left(10^{7}\right.$ cells $\left./ \mathrm{ml}\right)$ were incubated in PBS, 0 - and $10-\mathrm{mM} \mathrm{NaCl}$ choline buffers, $\mathrm{pH} 7.5$, at $37^{\circ} \mathrm{C}$ for $10 \mathrm{~min}$, after addition of Con A FITC $(100 \mu \mathrm{g} / \mathrm{ml})$. The cells were pelleted, washed once with buffer, resuspended, and counted again. Fluorescence was observed to be quenched when the Con A FITC bound, hence the cells were then sonicated, solubilized with Triton X-100 (0.2\% vol/vol) for $5 \mathrm{~min}$ and incubated with $220 \mathrm{mM} \alpha$-methylmannoside for $15 \mathrm{~min}$. This preparation was centrifuged at $10,000 \mathrm{~g}$ for $5 \mathrm{~min}$ and the fluorescence of the supernatant measured with excitation $495 \mathrm{~nm}$ and emission $520 \mathrm{~nm}$.

Monensin studies. Neutrophils were suspended to $5 \times 10^{7}$ cells $/ \mathrm{ml}$ in PBS, pH 7.2, containing $0.9 \mathrm{mM} \mathrm{CaCl}$ and $0.5 \mathrm{mM} \mathrm{MgCl}$. 5,6carboxyfluorescein was dissolved in dimethyl sulfoxide (DMSO) and then added to the cell suspension to a concentration of $50 \mu \mathrm{M}$ and the mixture incubated for $30 \mathrm{~min}$ at $22^{\circ} \mathrm{C}$. The cells were pelleted at $200 \mathrm{~g}$ for 6 min, resuspended in PBS, and stored at $4^{\circ} \mathrm{C}$. Using a Perkin-Elmer 650$10 \mathrm{~S}$ fluorescence spectrophotometer, emission at $520 \mathrm{~nm}$ was measured using $494 \mathrm{~nm}$ for excitation. Monensin (10 mM in ethanol) was added to the saline suspension to a final concentration of $10 \mu \mathrm{M}(6,19)$, and the increase in emission fluorescence (signifying cell alkalinization) was recorded. Using the same method as described above, $\mathrm{O}_{2}^{-}$generation was measured with addition of monensin $(10 \mu \mathrm{M})$ to cells in the saline buffer. Control experiments using ethanol were also performed.

Results are expressed as means \pm SEM, and differences were analyzed by the paired $t$ test and concluded to be statistically different at $P<0.05$. Intercepts of regression lines were compared by analysis of covariance using the method suggested by Zerbe et al. (20).

\section{Results}

Proton secretion. In $\mathrm{Na}^{+}$-free media, resting neutrophils secrete $\mathrm{H}^{+}$at a constant rate of $0.60 \pm 0.10 \mathrm{fmol} /$ cell per min. When $\mathrm{Na}^{+}(20 \mathrm{mM})$ is added to the media, the rate of $\mathrm{H}^{+}$secretion increased by $1.10 \pm 0.12 \mathrm{fmol} /$ cell per $\min (n=6, P<0.01)$. To further characterize the $\mathrm{Na}^{+}$dependency of $\mathrm{H}^{+}$secretion by neutrophils we examined the effect of progressive increments in media $\mathrm{Na}^{+}$concentrations $(1-10 \mathrm{mM})$ on the augmentation of $\mathrm{H}^{+}$secretion. These results are presented in Fig. 1 as a doublereciprocal plot $\left(\mathrm{Na}^{+}\right.$-independent effects subtracted). The enhancement of $\mathrm{H}^{+}$secretion by $\mathrm{Na}^{+}$follows first order kinetics. The calculated $K_{\mathrm{m}}$ for $\mathrm{Na}^{+}$in resting cells is $3.22 \pm 0.32 \mathrm{mM}$, and the $V_{\max }$ for $\mathrm{H}^{+}$secretion is $1.14 \pm 0.10 \mathrm{fmol} /$ cell per min.

When neutrophils in $\mathrm{Na}^{+}$-free media are incubated with $\mathrm{OZ}$, $\mathrm{H}^{+}$secretion is increased from $0.60 \pm 0.10$ to $2.20 \pm 0.11 \mathrm{fmol} /$ cell per $\min (n=5, P<0.001)$. In the presence of physiological concentrations of $\mathrm{Na}^{+}(140 \mathrm{mM})$, zymosan had even a greater stimulatory effect on $\mathrm{H}^{+}$secretion. It increased from $1.56 \pm 0.12$ to $4.24 \pm 0.12 \mathrm{fmol} /$ cell per $\min (n=6, P<0.01)$. This obser- 


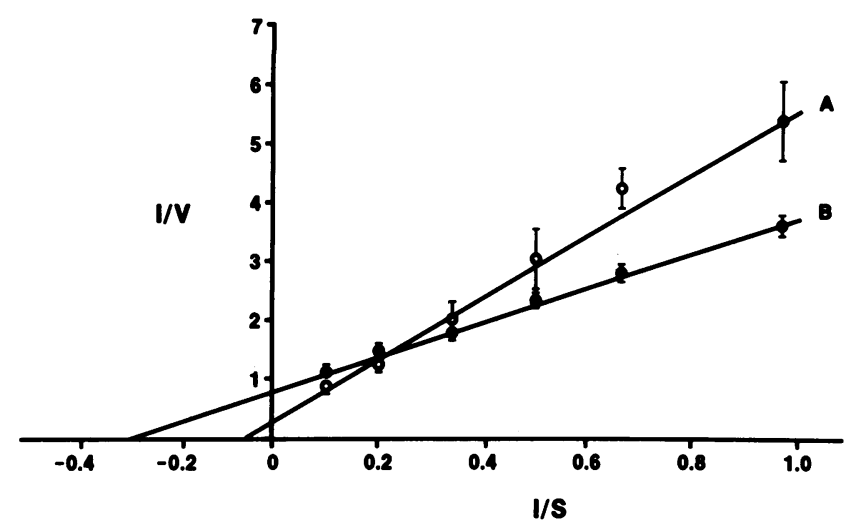

Figure 1. Sodium dependence of neutrophil proton secretion. Double reciprocal plot of the rate of $\mathrm{Na}^{+}$-dependent media acidification by $(A)$ zymosan-stimulated or $(B)$ resting neutrophils vs. media $\mathrm{Na}^{+}$concentration. $V$ is expressed as femtomoles $\mathrm{H}^{+}$per cell per minute and $S$ as $\mathrm{Na}^{+}$in meq. The lines were drawn by linear regression analysis. The equation for line $A$ is: $Y=(0.33 \pm 0.04)+(5.23 \pm 0.07)(X) ;(r=0.84$, $n=47, P<0.01)$, and for line $B: Y=(0.88 \pm 0.01)+(2.83 \pm 0.02)(X)$; $(r=0.93, n=47, P<0.01)$.

vation suggested to us that zymosan not only stimulates $\mathrm{Na}^{+}$independent but also $\mathrm{Na}^{+}$-dependent $\mathrm{H}^{+}$secretion. To characterize the kinetics of $\mathrm{Na}^{+}$-dependent portion of $\mathrm{H}^{+}$secretion in zymosan-treated cells, we also determined the effect of progressive increments in media $\mathrm{Na}^{+}$on $\mathrm{H}^{+}$secretion by stimulated neutrophils (Fig. 1). These studies indicate that $V_{\max }$ for $\mathrm{H}^{+}$secretion increased to $2.99 \pm 0.42 \mathrm{fmol} / \mathrm{cell}$ per min and the $K_{\mathrm{m}}$ for $\mathrm{Na}^{+}$increased to $15.65 \pm 0.62 \mathrm{mM}(n=6, P<0.05)$. Con A-stimulated cells also showed an increase in $\mathrm{Na}^{+}$-dependent $\mathrm{H}^{+}$secretion (data not shown).

These initial studies demonstrate that there is a moiety of $\mathrm{H}^{+}$secretion in both resting and stimulated neutrophils that is $\mathrm{Na}^{+}$dependent. Based on these observations we would suggest that there is a $\mathrm{Na}^{+} / \mathrm{H}^{+}$antiporter in the plasma membrane of these cells. If this proposal is correct, amiloride, a known competitive inhibitor of this antiporter (21), should reduce the $\mathrm{Na}^{+}$dependent rate of acidification. Amiloride at $5 \mu \mathrm{M}$ reduced the $\mathrm{Na}^{+}(10 \mathrm{mM})$ augmented rate of acidification of resting and zymosan-stimulated neutrophils by $59 \pm 1$ and $54 \pm 2 \%$, respectively $(n=11, P<0.05)$, and at $50 \mu \mathrm{M}$ amiloride, $\mathrm{H}^{+}$secretion was reduced by $>90 \%$. In Fig. 2, the effect of amiloride (0-15 $\mu \mathrm{M})$ on the $\mathrm{Na}^{+}\left(4\right.$ or $8 \mathrm{mM}$ ) augmented rate of $\mathrm{H}^{+}$secretion is shown. The $K_{\mathrm{i}}$ for amiloride derived from Fig. 2 is $1.02 \pm 0.04$ $\mu \mathrm{M}$ in resting cells and similar values were obtained in zymosanstimulated cells. The characteristics of the inhibitory effects of amiloride were also consistent with competitive antagonism. At $10 \mu \mathrm{M}$ amiloride, the $K_{\mathrm{m}}$ for $\mathrm{Na}^{+}$in resting cells was increased from $3.22 \pm 0.32$ to $11.2 \pm 0.61 \mathrm{mM}(n=5, P<0.05)$, but $V_{\max }$ was not significantly altered.

The effect of amiloride and its more potent analogue, dimethylamiloride, were studied at physiological $\mathrm{Na}^{+}$concentrations, since the above studies were all done in low $\mathrm{Na}^{+}$media. Given the inhibition characteristics previously determined, one would not expect amiloride, in the same concentrations, to affect $\mathrm{Na}^{+} / \mathrm{H}^{+}$exchange to a significant degree; however, dimethylamiloride appears in other cell types (22) to be approximately tenfold more potent than the parent compound; hence, some inhibition would be anticipated. The percent inhibition of the $\mathrm{Na}^{+}$-dependent $\mathrm{H}^{+}$secretion by neutrophils in physiological $\mathrm{Na}^{+}$buffer

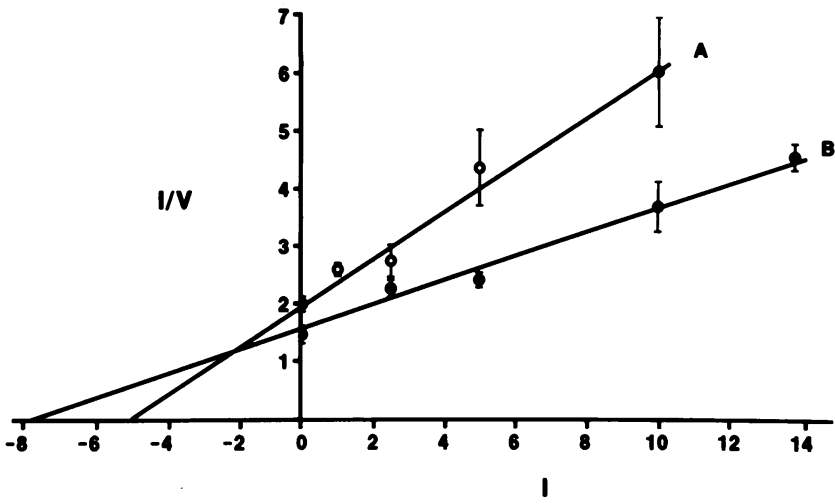

Figure 2. Amiloride inhibition of neutrophil proton secretion. The inverse of the rate of $\mathrm{Na}^{+}$-dependent media acidification by resting neutrophils vs. media amiloride concentration, at two concentrations of $\mathrm{Na}^{+} . V$ is expressed as femtomoles $\mathrm{H}^{+}$per cell per minute and $I$ as micromoles of amiloride. The lines were drawn by linear regression analysis. Line $A$ represents $4 \mathrm{mM} \mathrm{NaCl}$-containing buffer and line $B 8$ $\mathrm{mM} \mathrm{NaCl}$. The equation for line $A$ is: $Y=(2.03 \pm 0.09)+(0.41 \pm 0.02)$ $(X) ;(r=0.76, n=23, P<0.01)$, and for line $B: Y=(1.54 \pm 0.03)$ $+(0.21 \pm 0.01)(X) ;(r=0.92, n=23, P<0.01)$.

(145 mM) was determined at 100 - and $400-\mu \mathrm{m}$ concentrations of the inhibitors. In resting cells, $100 \mu \mathrm{m}$ dimethylamiloride achieved a $68.6 \pm 10.3 \%$ inhibition, as opposed to $25.7 \pm 2.3 \%$ for amiloride; in OZ-stimulated cells this concentration achieved $85.8 \pm 8.9$ and $36.0 \pm 11.9 \%$ inhibition, respectively $(n=4)$. At $400 \mu \mathrm{m}$, inhibition seen in resting cells with dimethylamiloride was $78.4 \pm 6.7 \%$, with amiloride $45.4 \pm 13.2 \%$; in OZ-stimulated cells it was $119.4 \pm 11.5$ and $73.8 \pm 18.8 \%$, respectively $(n=5)$. Under all conditions, the differences between amiloride and the analogue were significant at the $P<0.05$ level. This supports the finding of increased potency of the dimethylamiloride analogue seen in other cell types, and also demonstrates the importance of the $\mathrm{Na}^{+} / \mathrm{H}^{+}$antiporter at physiological $\mathrm{Na}^{+}$concentrations. At these higher concentrations, neither amiloride nor dimethylamiloride altered cell viability significantly as assessed by trypan blue exclusion. Neither ouabain $(100 \mu \mathrm{M})$, an $\mathrm{Na}^{+}-\mathrm{K}^{+}$ATPase inhibitor, nor SITS $(500 \mu \mathrm{M})$, an anion channel blocker, reduced $\mathrm{H}^{+}$secretion by resting or stimulated cells.

Cytoplast alkalinization. An alternative method to assess the presence of the $\mathrm{Na}^{+} / \mathrm{H}^{+}$antiporter in neutrophils is to demonstrate that there is $\mathrm{Na}^{+}$-dependent alkalinization of the cell. In these studies we used cytoplasts which are, in essence, large plasma membrane vesicles devoid of the nucleus and granules (14). These were used to avoid alteration of the fluorescent $\mathrm{pH}$ probe by $\mathrm{HOCl}$ formed by intact neutrophils in a myeloperoxidase-catalyzed reaction (17). The change in cytoplast $\mathrm{pH}$ was determined by the quench of acridine orange fluorescence (16). A representative experiment is presented in Fig. 3. Cytoplasts equilibrated to $\mathrm{pH} 6.0$ were added to a cuvette containing $\mathrm{Na}^{+}$free media $(\mathrm{pH} 7.5)$ and acridine orange, and the fluorescence was continually monitored in a spectrofluorometer. With the addition of cytoplasts there was a rapid fall in fluorescence, achieving a stable value within $2 \mathrm{~min}$. The decrement in fluorescence indicates that the interior of the cytoplasts are at a lower $\mathrm{pH}$ than the external media. When $\mathrm{Na}^{+}$was added there was an increase in fluorescence (alkalinization of the cytoplast). The initial rate of change in fluorescence after $\mathrm{Na}^{+}$addition is a function of the amount of $\mathrm{Na}^{+}$added to the system (Fig. 3). 


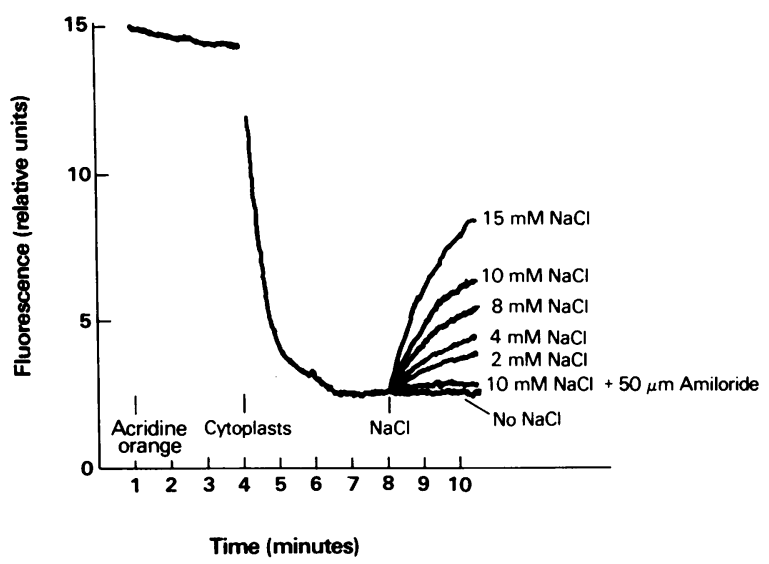

Figure 3. Representative experiment showing $\mathrm{Na}^{+} / \mathrm{H}^{+}$exchange in cytoplasts. Cytoplasts were equilibrated in a pH 6.0 buffer and added (final concentration, $0.6 \mathrm{mg}$ protein $/ \mathrm{ml}$ ) to a buffer containing acridine orange $(0.6 \mu \mathrm{M}), \mathrm{pH} 7.5$. A rapid quench in fluorescence was observed, but upon addition of $\mathrm{NaCl}$ a time-dependent rise in fluorescence (signifying cytosolic alkalinization) occurred. The $\mathrm{Na}^{+}$-dependent response was ablated when the cytoplasts were also incubated with $50 \mu \mathrm{M}$ amiloride.

The addition of $50 \mu \mathrm{M}$ amiloride to the cytoplasts markedly reduced the alkalinization induced by $\mathrm{Na}^{+}$addition. In Fig. 4 is presented a double-reciprocal plot of the rate of cytoplast alkalinization (the initial rate of increased fluorescence) vs. the concentration of $\mathrm{Na}^{+}$. The estimated $K_{\mathrm{m}}$ for $\mathrm{Na}^{+}$by the cytoplasts, $6.57 \pm 0.57 \mathrm{mM}$, was not significantly different from that of the intact neutrophils. When these studies were performed in the presence of $10^{-4} \mathrm{M}$ azide, an inhibitor of myeloperoxidase, similar results were obtained, indicating that the small contamination with myeloperoxidase had no effect on fluorescent measurements (17). In a separate group of cytoplast preparations, we also determined the rate of $\mathrm{Na}^{+}$-dependent alkalinization over a wider range of $\mathrm{Na}^{+}$concentrations (Fig. 5) than was used for the kinetic studies (Fig. 3). At $\mathrm{Na}^{+}$concentrations $>25 \mathrm{mM}$, the rate of cytoplast alkalinization did not significantly increase, demonstrating saturation of the antiporter.

To rule out the possible contribution of $\mathrm{Cl}^{-}$-dependent $\mathrm{H}^{+}$ transport pathways, $\mathrm{Na}^{+}$-dependent alkalinization was also evaluated in the same $\mathrm{Cl}^{-}$-free buffer. The change in fluorescence with addition of $25 \mathrm{mM}$ sodium cyclamate (30.7 21.6 fluorescence $\mathrm{U} / 50 \mu \mathrm{g}$ protein per $\min , n=5$ ) was not significantly different from that seen after addition of $25 \mathrm{mM} \mathrm{NaCl}(29.7 \pm 1.5$ fluorescence $\mathrm{U} / 50 \mu \mathrm{g}$ protein per $\min , n=5$ ). To insure that the $\mathrm{Na}^{+}$-dependent alkalinization noted above was an electro-

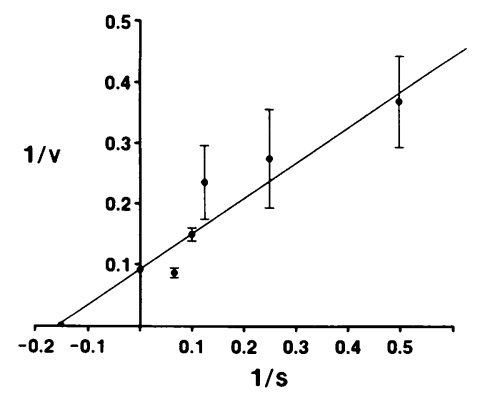

Figure 4. Double-reciprocal plot of the rate of cytoplast alkalinization vs. media $\mathrm{Na}^{+}$concentration. $V$ is expressed as the initial rate of change in fluorescence and $S$ as $\mathrm{Na}^{+}$in millimolars. The line was drawn by linear regression analysis. The equation is $Y=(0.09 \pm 0.02)$ $+(0.60 \pm 0.11)(X) ;(r$ $=0.79, n=20, P<0.05)$.

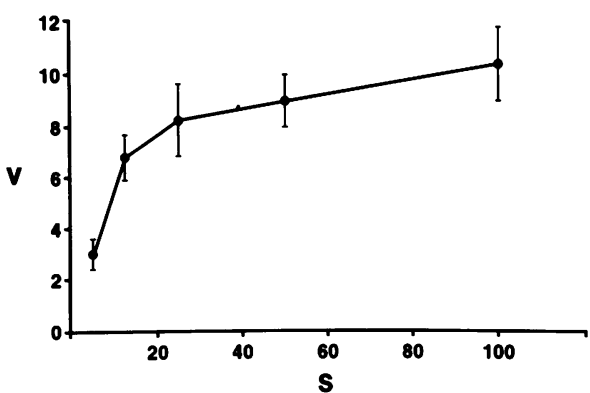

Figure 5. The rate of cytoplast alkalinization vs. media $\mathrm{Na}^{+}$concentration. $V$ represents the rate of change of fluorescence in the first two minutes, and $S$ the concentration of $\mathrm{Na}^{+}$in millimoles, $n=5$. The rate of alkalinization did not significantly increase above $25 \mathrm{mM} \mathrm{Na}^{+}$.

neutral process, the change in fluorescence upon addition of 25 $\mathrm{mM} \mathrm{NaCl}$ was observed in a high $\mathrm{K}^{+}$buffer, with and without valinomycin $(5 \mu \mathrm{g} / \mathrm{ml})$. No significant difference was observed between valinomycin-free $(20.3 \pm 4.9$ fluorescence $U / 50 \mu \mathrm{g}$ protein per $\min , n=5$ ), and valinomycin-containing media (18.8 \pm 1.2 fluorescence $\mathrm{U} / 50 \mu \mathrm{g}$ protein per min, $n=5$ ).

Antiporter function in the stimulated neutrophil. The $\mathrm{Na}^{+} /$ $\mathrm{H}^{+}$antiporter may be an important regulator of the respiratory burst function of neutrophils stimulated by a variety of agonists. To evaluate the role of the $\mathrm{Na}^{+} / \mathrm{H}^{+}$antiporter in this process we determined the effect of various $\mathrm{Na}^{+}$and amiloride concentrations on $\mathrm{O}_{2}^{-}$production by stimulated neutrophils (Fig. 6). The rate of $\mathrm{O}_{2}^{-}$generation by neutrophils incubated in physiologic control buffer (PBS) was compared with that of neutrophils incubated in $(a) \mathrm{Na}^{+}$-free choline buffer; $(b) 10 \mathrm{mM} \mathrm{Na}^{+}$-containing choline buffer; (c) $10 \mathrm{mM} \mathrm{Na}^{+}$-containing choline buffer with $50 \mu \mathrm{M}$ amiloride; and (d) PBS with $50 \mu \mathrm{M}$ amiloride. In the absence of $\mathrm{Na}^{+}, \mathrm{O}_{2}^{-}$production was significantly reduced (30\% of control buffer) in neutrophils stimulated with zymosan or Con A. In $10 \mathrm{mM} \mathrm{Na}^{+}$-containing media, the rate of $\mathrm{O}_{2}^{-}$ production was not different than control with both agonists. However, when $50 \mu \mathrm{M}$ amiloride was added to this low $\mathrm{Na}^{+}$ media, $\mathrm{O}_{2}^{-}$production was reduced to the same level as that in $\mathrm{Na}^{+}$-free media. This concentration of amiloride in low $\mathrm{Na}^{+}$media was shown in the above studies to completely inhibit $\mathrm{Na}^{+}$-dependent $\mathrm{H}^{+}$secretion by neutrophils. The presence of 50 $\mu \mathrm{M}$ amiloride in PBS did not significantly affect $\mathrm{O}_{2}^{-}$generation in cells stimulated by OZ or by Con A (Fig. 6).

The effect of dimethylamiloride in a physiologic buffer was again compared with amiloride at 100 - and $400-\mu \mathrm{m}$ concentrations. In OZ-stimulated cells, $100 \mu \mathrm{m}$ dimethylamiloride decreased $\mathrm{O}_{2}^{-}$production by $68.3 \pm 19.1 \%$ compared with $39.3 \pm 10.8 \%$ for amiloride; at $400 \mu \mathrm{m}, 102.0 \pm 16.6 \%$ compared with $82.5 \pm 17.1 \%$ was observed $(n=4, P<0.05)$. Thus, inhibition of $\mathrm{Na}^{+}$-dependent $\mathrm{H}^{+}$secretion by removal of extracellular $\mathrm{Na}^{+}$, addition of amiloride at low concentrations of extracellular $\mathrm{Na}^{+}$, or addition of a potent amiloride analogue to physiological $\mathrm{Na}^{+}$ buffers, markedly reduces $\mathrm{O}_{2}^{-}$production by stimulated neutrophils. In parallel studies of burst activation, the measurement of oxygen consumption exhibited the same $\mathrm{Na}^{+}$dependence as seen in the $\mathrm{O}_{2}^{-}$assays (data not shown). These findings cannot be explained by an inhibitory effect of amiloride on the NADPHoxidase. The respiratory burst enzymatic activity is assessed by the SOD-inhibitable reduction of cytochrome $c$ in a $27,000 \mathrm{~g}$ particulate preparation harvested from zymosan-stimulated 


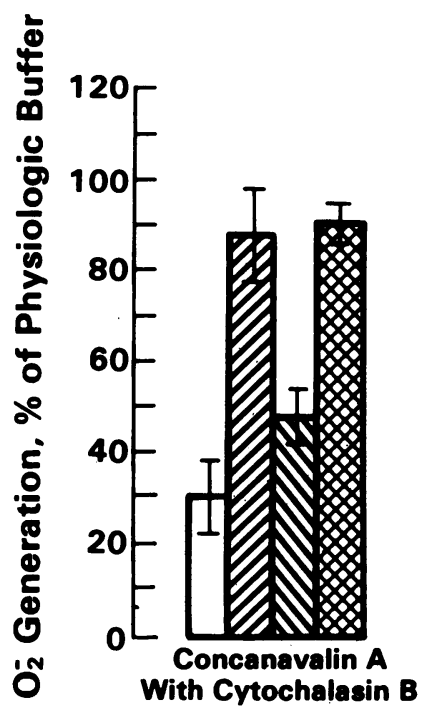

Figure 6. Effect of amiloride and various extracellular $\mathrm{Na}^{+}$concentration on $\mathrm{O}_{2}^{-}$generation by Con-A and zymosan-stimulated neutrophils. The results obtained in different buffers are expressed as a percentage of that obtained in PBS (nanomoles cytochrome $c$ reduced per minute per $10^{6}$ cells, mean \pm SEM, $n=5$; Con $\mathrm{A}=10.05 \pm 0.71 ; \mathrm{OZ}$

$=16.38 \pm 3.12, \mathrm{OZ}$ with cytochalasin $\mathrm{b}=5.95 \pm 1.87)$. A difference at

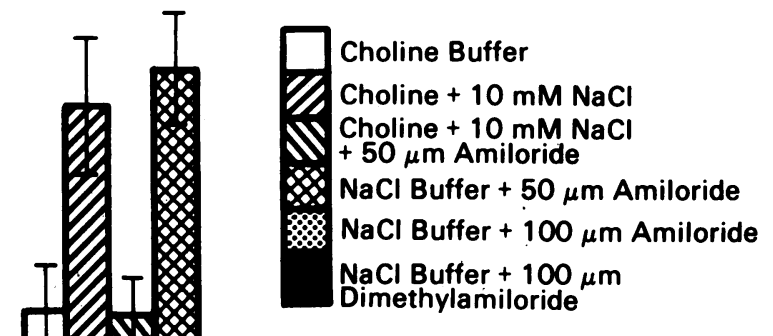

Opsonized Zymosan With Cytochalasin B neutrophils (2). In our standard $\mathrm{Na}^{+}$-free choline buffer, the addition of $100 \mu \mathrm{M}$ amiloride did not significantly alter the NADPH-oxidase activity (control: $8.68 \pm 2.20$ vs. choline buffer: $7.52 \pm 2.20 \mathrm{nmol} \mathrm{O}-1 / \mathrm{mg}$ per min, mean $\pm \mathrm{SD}, n=5$ ); thus, an effect on the assay of $\mathrm{O}_{2}^{-}$or the oxidase directly cannot account for the inhibitory effect of amiloride. Con A binding was not found to be significantly altered by changes in extracellular $\mathrm{Na}^{+}$ (data not shown).

The role of the antiporter in degranulation was investigated by measuring release of lysozyme from Con A-stimulated cells. The marked inhibition of release in $\mathrm{Na}^{+}$-free media $(41.9 \pm 7.5 \%$ of physiologic media, $n=6$ ) could be corrected to near normal levels $(80.9 \pm 6.7 \%, n=6)$ with addition of $10 \mathrm{mM} \mathrm{NaCl}$, but again inhibited $(49.7 \pm 5.6 \%, n=6)$ in the presence of $50 \mu \mathrm{M}$ amiloride. No effect of $50 \mu \mathrm{M}$ amiloride was seen in the physiologic buffer, again supporting a competitive inhibiting role for amiloride. This degranulation response was similar to $\mathrm{O}_{2}^{-}$generation in various concentrations of $\mathrm{Na}^{+}$, and in the presence of amiloride as shown in Fig. 6.

Effect of monensin on the respiratory burst. We interpret our data as demonstrating that the respiratory burst of stimulated neutrophils requires an active $\mathrm{Na}^{+} / \mathrm{H}^{+}$antiporter. However, since a cascade of events is involved upon stimulation of the cell, we sought to determine the effect of $\mathrm{Na}^{+} / \mathrm{H}^{+}$exchange alone on the respiratory burst. Monensin mediates $\mathrm{Na}^{+} / \mathrm{H}^{+}$exchange, and hence, upon its addition, cell alkalinization necessarily occurs with $\mathrm{Na}^{+}$influx. Neutrophils that had been incubated with the pH probe carboxyfluorescein were suspended in PBS, and a consistent rise in fluorescence was noted with addition of monensin $(10 \mu \mathrm{M})$, signifying cell alkalinization. However, under the same conditions, no $\mathrm{O}_{2}^{-}$generation could be detected, in accord with a previous report (6). This suggests that while extracellular $\mathrm{Na}^{+}$is necessary for a normal respiratory burst, its influx into the cell under these conditions is inadequate by itself to initiate NADPH-oxidase activation. the $P<0.05$ level is observed between $(a) \mathrm{O}_{2}^{-}$generated in choline alone and choline with $10-\mathrm{mM} \mathrm{NaCl}$ buffers, and $(b) \mathrm{O}_{2}^{-}$generated in choline with $10 \mathrm{mM} \mathrm{NaCl}$, and that same buffer with the addition of $50 \mu \mathrm{M}$ amiloride. Amiloride at $50 \mu \mathrm{M}$ had no significant effect in physiologic buffers, but $100 \mu \mathrm{m}$ amiloride and $100 \mu \mathrm{m}$ dimethylamiloride resulted in inhibition as shown.

\section{Discussion}

The protons secreted by the human neutrophil are derived from at least two sources: in the resting cell, lactic acid, and in the stimulated cell, primarily from the HMP shunt, by the dissociation of hydrated $\mathrm{CO}_{2}\left(\mathrm{H}_{2} \mathrm{CO}_{3} \rightarrow \mathrm{H}^{+}+\mathrm{HCO}_{3}^{-}\right)(3,4)$. In this study, we have characterized an important mechanism of $\mathrm{H}^{+}$ secretion in the neutrophil as the amiloride-sensitive $\mathrm{Na}^{+} / \mathrm{H}^{+}$ antiporter. In the absence of $\mathrm{Na}^{+}$, minimal $\mathrm{H}^{+}$secretion does occur, but this rate of secretion increases markedly with addition of millimolar concentrations of $\mathrm{Na}^{+}$. The $K_{\mathrm{m}}$ for $\mathrm{Na}^{+}$, the $K_{\mathrm{i}}$ for amiloride, the electroneutrality and the insensitivity to ouabain, and SITS strongly support our hypothesis that this antiporter is the same as described in the renal microvillus and in several other tissues $(13,23)$. The studies with cytoplasts used an entirely different method of measuring $\mathrm{H}^{+}$flux-the $\mathrm{pH}$-dependent change in fluorescence of acridine orange. By this method, similar $\mathrm{Na}^{+}$dependence and sensitivity to amiloride was observed, thus corroborating the finding of the $\mathrm{Na}^{+} / \mathrm{H}^{+}$antiporter in the intact cell.

In the stimulated neutrophil, the $\mathrm{Na}^{+} / \mathrm{H}^{+}$antiporter responds with an apparent increased $V_{\max }$ and a rise in the $K_{\mathrm{m}}$ for $\mathrm{Na}^{+}$. With cell stimulation, a host of metabolic changes rapidly occur (24) including $\mathrm{pH}$ change, $\mathrm{Na}^{+}$influx, protein phosphorylation, and fusion of granules with the plasma membrane. All of these events, with others, may change the ionic gradients and the number and efficiency of the antiporter units in the membrane, contributing to the change in the kinetics of the system $(13,25)$. Which entities are critical are yet to be defined.

With the complex metabolic events of the stimulated neutrophil, it is not surprising that a considerable rise in $\mathrm{Na}^{+}$-independent $\mathrm{H}^{+}$secretion is also seen. This may reflect increased lactate production, as well as activation of a magnesium-dependent electrogenic proton-translocating $\mathrm{H}^{+}$-ATPase (26). Despite these other mechanisms, a $\mathrm{Na}^{+}$-dependent and amiloride-sen- 
sitive pathway for $\mathrm{H}^{+}$secretion is important in the stimulated neutrophil.

The functional role of the $\mathrm{Na}^{+} / \mathrm{H}^{+}$antiporter has been initially characterized in these studies with the antiporter inhibitor, amiloride. When extracellular $\mathrm{Na}^{+}$is varied, receptor function may be altered (as recently demonstrated with neutrophils stimulated with FMLP [8]), and discernment of antiporter function from effects on receptor-ligand binding may not be made. In our studies of Con A-stimulated cells, decreased binding could not be involved as explaining the inhibitory effects seen with amiloride or in low $\mathrm{Na}^{+}$-containing buffers. Amiloride at 50 $\mu \mathrm{M}$ concentrations effectively inhibited $\mathrm{O}_{2}^{-}$generation in low $\mathrm{Na}^{+}$-containing buffers, when cells were stimulated with Con $\mathrm{A}$ or $\mathrm{OZ}$. At physiologic $\mathrm{Na}^{+}$concentrations with higher amiloride concentrations, and with dimethylamiloride, this inhibition was again observed, supporting a competitive inhibitory role for amiloride in this process. Degranulation also appears to be dependent upon a functional $\mathrm{Na}^{+} / \mathrm{H}^{+}$antiporter. In Con A-stimulated cells, both absence of $\mathrm{Na}^{+}$or presence of amiloride in low $\mathrm{Na}^{+}$media markedly inhibited lysozyme release, whereas amiloride had no effect in physiologic $\mathrm{Na}^{+}$concentrations. Hence, the $\mathrm{Na}^{+} / \mathrm{H}^{+}$antiporter appears to be a crucial entity for normal degranulation and respiratory burst activation in the human neutrophil.

Given the sensitivity of the respiratory burst to extracellular $\mathrm{Na}^{+}$concentration and to amiloride at low $\mathrm{Na}^{+}$concentrations, it might be expected that $\mathrm{Na}^{+} / \mathrm{H}^{+}$exchange initiated by an ionophore such as monensin would stimulate the burst. However, while mediating $\mathrm{Na}^{+} / \mathrm{H}^{+}$exchange to a similar extent as observed with $\mathrm{OZ}$ or Con $\mathrm{A}$, monensin was unable by itself to activate $\mathrm{O}_{2}^{-}$production. Extracellular $\mathrm{Na}^{+}$then is crucial for normal cell activation, but its influx, with resultant intracellular alkalinization, is insufficient alone. This supports a secondary role for the $\mathrm{Na}^{+} / \mathrm{H}^{+}$antiporter (27), a modulator but not an initiator of cell activation. How the antiporter modulates the respiratory burst is unclear, however its contribution to the acid base homeostasis in the cell is significant; hence, it may affect cellular function by its role in maintaining intracellular $\mathrm{pH}$, which in many systems modifies cell function $(28,29)$.

Amiloride has been shown to block $\mathrm{Na}^{+} / \mathrm{Ca}^{++}$exchange in erythroleukemia cells (30) and in microsomes of rat cerebral cortex $(31,32)$; hence, theoretically amiloride could mediate its effect on the respiratory burst through its direct effects on calcium flux. However, these previous studies show that only at high amiloride concentrations $(1-2 \mathrm{mM})$ is the $\mathrm{Na}^{+} / \mathrm{Ca}^{++}$exchange affected. Hence, the concentrations of amiloride found in our study to inhibit $\mathrm{O}_{2}^{-}$generation are consonant with blocking $\mathrm{Na}^{+} /$ $\mathrm{H}^{+}$exchange rather than directly effecting $\mathrm{Na}^{+} / \mathrm{Ca}^{++}$exchange.

By the $K_{\mathrm{m}}$ for $\mathrm{Na}^{+}$and inhibition characteristics of amiloride, a $\mathrm{Na}^{+} / \mathrm{H}^{+}$antiporter similar to that in other cells has been defined in the neutrophil. What specific role the $\mathrm{Na}^{+} / \mathrm{H}^{+}$antiporter has in the activation sequence of the respiratory burst oxidase and degranulation response is yet to be defined, however, this $\mathrm{Na}^{+}$/ $\mathrm{H}^{+}$antiporter appears linked to these functions. Whether the antiporter passively accommodates to the increased $\mathrm{H}^{+}$load of the stimulated cell, is directly modified by phosphorylation, as recently shown in HL-60 cells (11), or is modified by phospholipase activation as in fibroblasts (27), are important relationships to define for its functional characterization. While each of these activities are activated in the stimulated neutrophil (24), their respective relations to each other are yet to be elucidated.

\section{Acknowledgments}

The authors gratefully acknowledge Ms. Ann Marie Happnie for secretarial aid in preparation of the manuscript.

This work was supported by National Institutes of Health grants AI20064 and AM-20611. Dr. Schwartz is an established investigator of the American Heart Association, with funds contributed in part by the American Heart Association Massachusetts Affiliate, Inc. Dr. Wright is the recipient of a research fellowship award from the Arthritis Foundation.

\section{References}

1. Badwey, J., and M. L. Karnovsky. 1980. Active oxygen species and the functions of phagocytic leukocytes. Annu. Rev. Biochem. 49: 695-726.

2. Light, D. R., C. Walsh, A. M. O'Callaghan, E. J. Goetzl, and A. I. Tauber. 1981. Characteristics of the cofactor requirements for the $\mathrm{O}_{2}^{-}$-generating NADPH-oxidase of human polymorphonuclear leukocytes. Biochemistry. 20:1468-1476.

3. Borregaard, N., J. H. Schwartz, and A. I. Tauber. 1984. Proton secretion by stimulated neutrophils: significance of hexose monophosphate shunt activity as source of electrons and protons for the respiratory burst. J. Clin. Invest. 74:455-459.

4. van Zweiten, R., R. Wever, M. N. Hamers, R. S. Weening, and D. Roos. 1981. Extracellular proton release by stimulated neutrophils. J. Clin. Invest. 68:310-313.

5. Simchowitz, L., and I. Spilberg. 1979. Chemotactic factor-induced generation of superoxide radicals by human neutrophils: evidence for the role of sodium. J. Immunol. 123:2428-2435.

6. Korchak, H. M., and G. Weissmann. 1980. Stimulus-response coupling in the human neutrophil. Transmembrane potential and the role of extracellular $\mathrm{Na}^{+}$. Biochim. Biophys. Acta. 601:180-194.

7. Bianca, V. D., P. Bellavite, P. DeTogni, R. Fumarulo, and F. Rossi. 1983. Studies on stimulus-response coupling in human neutrophils. I. Role of monovalent cations in the respiratory and secretory response to N-formylmethionylleucylphenylalanine. Biochim. Biophys. Acta. 755: 497-505.

8. DeTogni, P., V. D. Bianca, P. Bellavite, M. Grzeskowiak, and F. Rossi. 1983. Studies on stimulus-response coupling in human neutrophils. II. Relationships between the effects of changes of external ionic composition on the properties of $\mathrm{N}$-formylmethionylleucylphenylalanine receptors and on the respiratory and secretory responses. Biochim. Biophys. Acta. 755:506-513.

9. Simchowitz, L., I. Spilberg, and P. deWeer. 1982. Sodium and potassium fluxes and membrane potential of human neutrophils. Evidence for an electrogenic sodium pump. J. Gen. Physiol. 79:453-479.

10. Sha'afi, R. I., T. F. P. Molski, and P. H. Naccache. 1981. Chemotactic factors activate differentiable permeation pathways for sodium and calcium in rabbit neutrophils. Effect of amiloride. Biochem. Biophys. Res. Commun. 99:1271-1275.

11. Besterman, J. M., and P. Cuatrecasas. 1984. Phorbol esters rapidly stimulate amiloride-sensitive $\mathrm{Na}^{+} / \mathrm{H}^{+}$exchange in a human leukemic cell line. J. Cell Biol. 99:340-343.

12. Grinstein, S., and W. Furuya. 1984. Amiloride-sensitive $\mathrm{Na}^{+} /$ $\mathrm{H}^{+}$exchange in human neutrophils: mechanism of activation by chemotactic factors. Biochem. Biophys. Res. Commun. 122:755-762.

13. Aronson, P. S. 1983. Mechanisms of active $\mathrm{H}^{+}$secretion in the proximal tubule. Am. J. Physiol. 14:F647-F659.

14. Roos, D., A. A. Voetman, and L. J. Meerrhof. 1983. Functional activity of enucleated human polymorphonuclear leukocytes. J. Cell Biol. 97:368-377.

15. Borregaard, N., and A. I. Tauber. 1984. Subcellular localization of the human neutrophil NADPH-oxidase. b-cytochrome and associated flavoprotein. J. Biol. Chem. 259:47-52.

16. Lee, M. C., J. G. Forte, and D. Epel. 1982. The use of fluorescent amines for the measurement of pHi; applications in liposomes, gastric microsomes and sea urchin gametes. In Intracellular pH: Its Measure- 
ment, Regulation and Utilization in Cellular Function. R. Nuccitelli and D. W. Deamer, editors. Alan R. Liss Inc., NY. 135-160.

17. Hurst, J. K., J. M. Albrich, T. R. Green, H. Rosen, and S. Klebanoff. 1984. Myeloperoxidase-dependent fluorescein chlorination by stimulated neutrophils. J. Biol. Chem. 259:4812-4821.

18. Klass, H. J., J. Hopkins, G. Neale, and T. J. Peters. 1977. The estimation of serum lysozyme: a comparison of four assay methods. Biochem. Med. 18:52-57.

19. DiVirgilio, F., and B. D. Gomperts. 1983. Ionophore monensin induces $\mathrm{Na}^{+}$-dependent secretion from rabbit neutrophils. Requirement for intracellular $\mathrm{Ca}^{2+}$ stores. Biochim. Biophys. Acta. 763:292-298.

20. Zerbe, G. O., P. G. Archer, P. Banchero, and A. J. Lechner. 1982. On comparing regression lines with unequal slopes. Am. J. Physiol. 242: R178-R180.

21. Benos, D. J. 1982. Amiloride: a molecular probe of sodium transport in tissues and cells. Am. J. Physiol. 242:C131-C145.

22. L'Allemain, G., A. Franchi, E. Cragoe, Jr., and J. Pouysseger. 1984. Blockade of the $\mathrm{Na}^{+} / \mathrm{H}^{+}$antiport abolishes growth factor-induced DNA synthesis in fibroblasts. J. Biol. Chem. 259:4313-4319.

23. Ives, H. E., and F. C. Rector. 1984. Proton transport and cell function. J. Clin. Invest. 73:285-290.

24. Tauber, A. I., N. Borregaard, E. R. Simons, and J. Wright. 1983. Chronic granulomatous disease: a syndrome of phagocyte oxidase deficiencies. Medicine. 62:286-309.
25. Grinstein, S., J. D. Goetz, and A. Rothstein. 1984. $\mathrm{Na}^{+}$fluxes in thymic lymphocytes. J. Gen. Physiol. 84:585-600.

26. Mollinedo, F., and D. L. Schneider. 1984. Subcellular localization of cytochrome $b$ and ubiquinone in a tertiary granule of resting human neutrophils and evidence for a proton pump ATPase. J. Biol. Chem. 259:7143-7150.

27. Vincentini, L. M., R. J. Miller, and M. L. Villereal. 1984. Evidence for a role of phospholipase activity in the serum stimulation of $\mathrm{Na}^{+}$flux in human fibroblasts. J. Biol. Chem. 259:6912-6919.

28. Busa, W. B., and R. Nuccitelli. 1984. Metabolic regulation via intracellular pH. Am. J. Physiol. 246:R409-R438.

29. Tauber, A. I., and E. J. Goetzl. 1979. Structural and catalytic properties of the solubilized superoxide-generating activity of human polymorphonuclear leukocytes. Biochemistry. 18:5576-5584.

30. Smith, R. L., I. G. Macara, R. Levenson, D. Housman, and L. Cantly. 1982. Evidence that a $\mathrm{Na}^{+}-\mathrm{Ca}^{2+}$ antiport system regulates murine erythroleukemia cell differentiation. J. Biol. Chem. 257:773-780.

31. Schellenberg, G. D., L. Anderson, and P. D. Swanson. 1983. Inhibition of $\mathrm{Na}^{+}-\mathrm{Ca}^{2+}$ exchange in rat brain by amiloride. Mol. Pharmacol. 24:251-258.

32. Swanson, P. D., G. D. Schellenberg, and L. Anderson. 1983. Effects of amiloride and analogue on $\mathrm{Na}^{+}-\mathrm{Ca}^{2+}$ exchange in synaptic plasmalemma vesicles and on metabolism in cerebral slices. J. Neurochem. 41:S160C. 